\title{
Contributions and challenges of physical education professionals at the Center for Psychosocial Support
}

\author{
Contribuições e desafios do profissional de Educação Física no Centro de \\ Atenção Psicossocial
}

Sulamita Emy Tavares de Oliveira Mendonça Soares', Mateus Gustavo de Farias Brainer', Charles Barbosa Gomes da Silva', Ameliane da Conceição Reubens Leonidio², Emmanuelly Correia de Lemos²

\begin{abstract}
This cross-sectional, descriptive, quantitative, and qualitative study aimed to investigate the contributions and challenges of physical education professionals working at the Center for Psychosocial Support (CPSS) in Recife, Brazil. The study population was composed of CPSS professionals and professionals from the Academia da Cidade Program (ACP) who worked at the CPSS. Data were collected using a self-administered questionnaire, which was administered to professionals from all 17 CPSS and from ACP centers in Recife during previously scheduled visits to these sites. The following variables were assessed: sociodemographic data, initial and ongoing training, and aspects regarding the level of integration between these two health care services. Data were stored and organized using the EpiData software, version 3.1, and then analyzed using SPSS, version 10.0. Results are presented in absolute and relative frequencies. We used content analysis to analyze the qualitative data. The study included 115 CPSS professionals and $24 \mathrm{ACP}$ professionals. More than half of both respondent groups rated ACP participation in the CPSS as very important for users; however, the level of integration between these two services was rated as moderate or poor, and these results were reinforced in the analysis of the qualitative questions. We conclude that the participation of physical education professionals in the CPSS brings contributions related to users' benefits and teamwork at both services, but structural and work process issues were challenges that need to be overcome in order to allow a more qualified and integrated performance from these professionals.
\end{abstract}

\section{Keywords}

Physical Education; Health Professional; Mental Health; Physical Activity; Work .

\section{Resumo}

Este estudo teve como objetivo analisar as contribuições e desafios da atuação do profissional de Educação Física no Centro de Atenção Psicossocial (CAPS) do Recife. Estudo transversal, descritivo, de abordagem quantitativa e qualitativa. A população do estudo foi composta por profissionais dos CAPS e do Programa Academia da Cidade (PAC) que atuavam nesses Centros, a coleta de dados ocorreu por meio de questionários autoaplicado, sendo aplicados nos 17 CAPS e nos polos do PAC a partir de visita pré-agenda nesses locais. As variáveis analisadas foram: sociodemográfico, formação inicial e permanente, além de aspectos sobre a integração entre esses dois serviços de saúde. A tabulação dos dados foi efetuada no programa EpiData Entry v.3.1, para análise dos dados quantitativos foi utilizado o SPSS $v$. 10.0, resultados apresentados em frequências relativas e absolutas e para análise qualitativa, utilizou-se a técnica de Análise de Conteúdo. Participaram do estudo 115 profissionais do CAPS e 24 do PAC, para os dois grupos de profissionais estudados, mais da metade atribuiu ser muito importante a intervenção do PAC no CAPS para os usuários. Porém, consideraram a integração desses serviços regular e ruim, aspectos que foram reforçados na análise das questões qualitativas. Concluise que existem contribuições na atuação do profissional de Educação Física nos CAPS, que essas se relacionam tanto com benefícios para os usuários como para o trabalho em equipe desses serviços, por outro lado questões estruturais e de processo de trabalho foram encontrados como desafios para que essa atuação seja mais qualificada e integrada.

\section{Palavras-chave}

Educação Física; Profissional da saúde; Saúde mental; Atividade física; Trabalho.
1 Higher School of Physical Education, University of Pernambuco, Lato Sensu Specialization Program

2 Higher School of Physical Education, University of Pernambuco, Stricto Sensu Postgraduate Program.

\section{Introduction}

In recent decades the Brazilian mental health model has gone through several changes, which arose from 
social debates and movements for the civil and political rights of mental health users, more humane treatment, and psychiatric non-institutionalization. This process became known as psychiatric reform and culminated with the publication of Law 10.216/01 and Decree 336/02, which made the Center for Psychosocial Support (CPSS) the legitimate alternative to traditional psychiatric hospitals ${ }^{1,2}$.

The CPSS receives people with severe mental disorders and substance-related disorders. It is characterized by the intensive use of a large and complex set of therapeutic technologies that aim to contribute to social reinsertion through work, recreation, the exercising of civil rights, and the strengthening of family and community ties ${ }^{3,4}$.

This service is the main component of the Psychosocial Care Network (PSCN), which includes primary care and other sectors of society ${ }^{5}$. Thus, a new way of thinking and acting in the context of management and intervention is recommended and requires the re-adaptation or adaptation of health professionals, as well as the incorporation of other professionals in order to provide a more humane and effective care ${ }^{6}$.

This scenario reinforces the need for multidisciplinary teams who work in an interdisciplinary way, because the therapeutic process requires work that is composed of built, shared, and reinvented knowledge. The aim of this knowledge is to fill possible knowledge gaps that might exist in the different disciplines in order to solve certain problems and assist in the development of Individual Therapeutic Projects (ITP), which are utilized as a guiding instrument for the therapeutic management of each user ${ }^{3,7,8}$.

Thus, CPSS teams are composed professionals of middle education level, such as nurse technicians, nursing assistants and administrative staff; and professionals of higher education level, such as nurses, physicians, psychologists, social workers, occupational therapists, educators, physical education professionals or other professionals other professionals, depending on the activities offered ${ }^{3,8}$.

From this perspective, although physical education professionals (PEP) may perform activities common to all CPSS professionals, such as initial user reception, coordination between primary, secondary, and tertiary care sectors, and ITP implementation, they usually promote experiences with physical activity and practices in specific interventions in the field ${ }^{9-11}$.

In 2002, PEP were inserted in the CPSS in Recife. These professionals are connected to the Academia da Cidade Program (ACP), a program designed to promote health through physical activity and healthy nutrition. PEP divide their working hours ( $30 \mathrm{~h} /$ week) between ACP and CPSS activities. At the CPSS, they are responsible for the supervision of the "Grupo Movimento" (Movement Group, in English), which offers adapted sports, dance, gymnastics, wrestling, and capoeira classes, among other physical activities and practices. ${ }^{12,13}$.

However, since undergraduate physical education courses do not have a tradition of training students to work in mental health settings and most researches on the relationship between physical activity and mental health focus on the effects of physical activity on physical and psychic parameters, it becomes necessary to discuss the concepts, actions, challenges and possible contributions of PEP interventions in the CPSS ${ }^{10}$.

Thus, this study aimed to investigate the contributions and challenges of physical education professionals working at the Center for Psychosocial Support (CPSS) in Recife, Brazil. 


\section{Methods}

This study cross-sectional, descriptive, quantitative, and qualitative study ${ }^{14-16}$ is part of a research project called "Insertion of the Academia da Cidade Program in Centers for Psychosocial Support in Recife: professionals' knowledge and practices", conducted by students of the Specialization Course in Physical Activity and Public Health of the Higher School of Physical Education, University of Pernambuco.

Study sites were all 17 CPSS and the ACP centers in Recife. The study population was composed of CPSS professionals of different disciplines and professionals from the Academia da Cidade Program (ACP) who worked at the CPSS. The expected sample size was 170 CPSS professionals. It was calculated to include at least one professional from each discipline available at the CPSS. Then we included 10 workers from each CPSS. As for the physical education professionals from the ACP who worked at the CPSS, tried to obtain the maximum sample size possible, i.e. 24 professionals, due to the importance of $100 \%$ participation. Forty-six CPSS professionals were lost due to absence from work on data collection days and 9 refused to participate in the study, totaling 55 losses. There were no losses among the ACP professionals. Thus, the final sample was composed of $115 \mathrm{mem}$ bers of the CPSS multidisciplinary team and 24 ACP professionals.

Data were collected using two self-administered questionnaires - one for CPSS professionals and one for ACP professionals. Both questionnaires included open and close-ended questions and their content was derived from previous studies on the topic ${ }^{9,12}$. They were organized in three sections, namely: (1) sociodemographic data and initial training; (2) ongoing training and professional performance; and (3) level of integration between the CPSS and the ACP. Of note, in addition to the same sections and similar questions, the questionnaires also included questions specific to each of the two study groups. The variables assessed in this study are described below (Chart 1):

\begin{tabular}{|c|c|c|}
\hline Population & Section and variables analyzed & Response categories \\
\hline \multirow{3}{*}{$\begin{array}{l}\text { Professionals of the } \\
\text { ACP who work at the } \\
\text { CPSS and } \\
\text { CPSS professionals }\end{array}$} & $\begin{array}{l}\text { (1) sociodemographic data and initial training } \\
\text { - Sex } \\
\text { - Age group } \\
\text { - Educational level } \\
\text { - Academic training }\end{array}$ & \multirow{3}{*}{$\begin{array}{l}\text { - Female and Male } \\
\text { - } \quad \text { } \text { mears } \\
\text { level, others. } \\
\text { - } \quad \text { education level, others. } \\
\text { - } \text { social services, nursing, medicine, physical } \\
\text { therapy, physical education, occupational } \\
\text { therapy, psychology, pharmacy, speech } \\
\text { therapy, nutrition, others, not applicable. } \\
\text { - Years } \\
\text { - Years } \\
\text { - Yes, No } \\
\text { - } \quad \text { Yes, No } \\
\text { - Not important, little important, important, } \\
\text { very important. } \\
\text { - Very poor, poor, moderate, good, very good. }\end{array}$} \\
\hline & 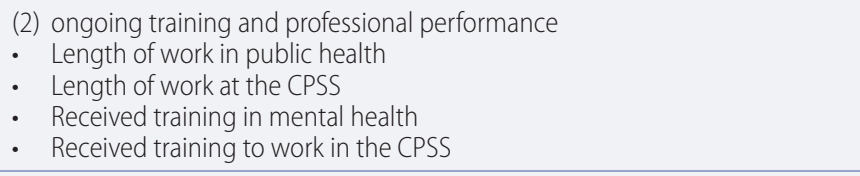 & \\
\hline & $\begin{array}{l}\text { (3) level of integration between the CPSS and the ACP } \\
\text { - Importance of the intervention of PEP from the ACP for the ITP of CPSS users } \\
\text { - Importance of the intervention of PEP from the ACP for the family } \\
\text { - Importion of CPSS users } \\
\text { healthy lifestyles by CPSS users } \\
\text { - Importance of the intervention of PEP from the ACP to reduce the anxiety } \\
\text { and fatigue of CPSS users } \\
\text { - Importance of the intervention of PEP from the ACP to improve self- } \\
\text { - } \text { Perteem of CPSS users } \\
\text { - Positive aspects of the intervention of PEP in the CPSS } \\
\text { - Negative aspects (that need to be improved) of the intervention of PEP in the CPSS }\end{array}$ & \\
\hline
\end{tabular}

CHART 1 - Distribution of the analyzed variables.

PEP:Physical education professional ACP: Academia da Cidade Program. CPSS: Center for Psychosocial Support.

Data collection was performed by students from the Specialization Course of the University of Pernambuco, who had been previously trained to administer the 
questionnaire. The data were collected from August to September 2015 during previously scheduled visits to the CPSS and the ACP centers.

Data were stored and organized using the EpiData software, version 3.1. Participants' responses to the close-ended questions were analyzed using SPSS, version 10.0. Results are presented in absolute and relative frequencies.

Responses to open-ended questions were analyzed using content analysis, which was performed in the following steps: data reading, data sorting, rereading and data codification ${ }^{17}$. Word frequency was used as the unit of analysis, and contributed to the subsequent creation of categories and subcategories. Word counting was performed using the Aquad 7 software. The analytical categories and subcategories are presented as diagrams.

The research project to which this study is connected was approved by the Ethics Committee on Human Research of the University of Pernambuco - CAAE: 46013415.3.0000.5192. All participation was voluntary and informed consent was obtained.

\section{Results}

With regard to sociodemographic data, most participants were female (58.3\% ACP and $87.0 \%$ CPSS); aged $30-39$ years (87.5\% ACP and 40,9\% CPSS); and had completed higher education (100.0\% ACP and $71.3 \%$ CPSS). As for their initial training, all ACP participants were physical education professionals (100\%) and most CPSS participants were 'psychologists (27.0\%), occupational therapists (20.0\%), nurses (18.,0\%) and social workers (14.0\%) who had been working in public health (100.0\% ACP and 50.4\% CPSS) and at the CPSS (100.0\% ACP and 69.6\% CPSS) for 2 to 10 years.

Both the ACP and the CPSS professionals had not received any specific training in Mental Health (79.2\% and 53.5\%, respectively). Likewise, most ACP and CPSS professionals reported having no specific training to work at the CPSS (78.3\% ACP and $53.5 \%$ CPSS), as shown in Table 1.

Most respondents from both groups rated the contributions of physical education professionals' participation in the CPSS as "very important". Moreover, the majority of respondents rated the level of integration between the ACP and the CPSS and "moderate" or "poor", as shown in Table 2.

Based on the word-frequency count of the responses to the questionnaire's open-ended questions, the following category was created: positive aspects of the intervention of PEP from the ACP in the CPSS. This category included the subcategories Benefits of exercise and physical activity: Prof. 3CPSS "[...] Creating physical activity habits. Care and increased self-esteem [...]"; Prof. 1ACP "[...] The role of exercises in reducing clinical symptoms [...]"; Incentives to healthy lifestyles and health promotion: Prof. 1CPSS "[...] guidance on bealthy lifestyle, such as: nutrition, self-care, body care [...]"; Prof. $11 A C P$ "Give users the opportunity to acquire knowledge on bealthy lifestyles"; Users' reinsertion and socialization: Prof. 23CPSS '[...] encourages users' integration and socialization [...]"; Prof. 12ACP "Improves users' socialization and integration [...]"; and Teamwork: Prof. 8CPSS "Integration with the CPSS team [...]"; Prof. 24ACP "[...] work together with other professionals to sum up knowledge and actions in a multidisciplinary manner [...]".

In addition to these categories, which were similar for both groups, Participation in the ITP was considered to be a positive aspect only by ACP professionals: Prof. 15ACP "To contribute to users' ITP as part of the multidisciplinary team [...]"; Prof. $23 A C P$ " $[. .$.$] to help the team achieve a different way of looking at things and developing the$ ITP [...]". The category positive aspects of the intervention of PEP from the ACP in the 
TABLE 1 - Distribution of sociodemographic, training and professional performance data of ACP and CPSS professionals. Recife, Brazil, 2015.

\begin{tabular}{|c|c|c|c|c|}
\hline \multirow{2}{*}{ Variable } & \multicolumn{2}{|c|}{ ACP professional } & \multicolumn{2}{|c|}{ CPSS professional } \\
\hline & $\mathrm{N}$ & $\%$ & $\mathrm{~N}$ & $\%$ \\
\hline \multicolumn{5}{|l|}{ Sex } \\
\hline Female & 14 & 58.3 & 100 & 87.0 \\
\hline Male & 10 & 41.7 & 15 & 13.0 \\
\hline \multicolumn{5}{|l|}{ Age group } \\
\hline $20-29$ & 1 & 4.2 & 09 & 7.8 \\
\hline $30-39$ & 21 & 87.5 & 47 & 40.9 \\
\hline $40-49$ & 2 & 8.3 & 27 & 23.5 \\
\hline $50-59$ & 0 & 0.0 & 29 & 25.2 \\
\hline $60-69$ & 0 & 0.0 & 03 & 2.6 \\
\hline \multicolumn{5}{|l|}{ Educational level } \\
\hline High school & 0 & 0.0 & 10 & 8.7 \\
\hline Incomplete higher education & 0 & 0.0 & 04 & 3.5 \\
\hline Complete higher education & 24 & 100 & 82 & 71.3 \\
\hline Others & 0 & 0.0 & 19 & 16.5 \\
\hline \multicolumn{5}{|l|}{ Academic training } \\
\hline Social Services & 0 & 0.0 & 14 & 14.0 \\
\hline Physical Education & 24 & 100.0 & 01 & 1.0 \\
\hline Nursing & 0 & 0.0 & 18 & 18.0 \\
\hline Occupational Therapy & 0 & 0.0 & 20 & 20.0 \\
\hline Medicine & 0 & 0.0 & 08 & 8.0 \\
\hline Psychology & 0 & 0.0 & 27 & 27.0 \\
\hline Physical Therapy & 0 & 0.0 & 01 & 1.0 \\
\hline Pharmacy & 0 & 0.0 & 07 & 7.0 \\
\hline Speech Therapy & 0 & 0.0 & 01 & 1.0 \\
\hline Others & 0 & 0.0 & 03 & 3.0 \\
\hline \multicolumn{5}{|l|}{ Length of work in public health } \\
\hline $2-10$ years & 24 & 100.0 & 58 & 50.9 \\
\hline $11-20$ years & 0 & 0.0 & 35 & 30.7 \\
\hline $21-30$ years & 0 & 0.0 & 18 & 15.8 \\
\hline $31-40$ years & 0 & 0.0 & 03 & 2.6 \\
\hline \multicolumn{5}{|l|}{ Length of work at the CPSS } \\
\hline $2-10$ years & 24 & 100.0 & 80 & 70.2 \\
\hline $11-20$ years & 0 & 0.0 & 32 & 28.1 \\
\hline $21-30$ years & 0 & 0.0 & 02 & 1.8 \\
\hline \multicolumn{5}{|l|}{ Received training in mental health } \\
\hline Yes & 4 & 16.7 & 52 & 46.4 \\
\hline No & 19 & 79.2 & 60 & 53.6 \\
\hline \multicolumn{5}{|c|}{ Received training to work in the CPSS } \\
\hline Yes & 5 & 21.7 & 53 & 46.5 \\
\hline No & 18 & 78.3 & 61 & 53.5 \\
\hline
\end{tabular}

ACP Academia da Cidade Program CPSS: Center for Psychosocial Support.

CPSS and its corresponding subcategories are presented in Figure 1.

Another emerging category dealt with negative aspects of the intervention of PEP from the ACP in the CPSS. Some of the aspects mentioned were the lack or inadequacy of and/or the need to the expand the Physical space: Prof. 51CPSS "[...] too poor 
TABLE 2 - Distribution of the level of importance ascribed to the intervention of PEP of the ACP in the CPSS, according to ACP and CPSS professionals. Recife, Brazil, 2015.

\begin{tabular}{|c|c|c|c|c|}
\hline \multirow{2}{*}{ Variable } & \multicolumn{2}{|c|}{ ACP professional } & \multicolumn{2}{|c|}{ CPSS professional } \\
\hline & N & $\%$ & N & $\%$ \\
\hline \multicolumn{5}{|c|}{ Importance of the intervention of PEP from the ACP for the ITP of CPSS users } \\
\hline Important & 9 & 37.5 & 36 & 31.9 \\
\hline Very important & 15 & 62.5 & 77 & 68.1 \\
\hline \multicolumn{5}{|c|}{ Importance of the intervention of PEP from the ACP for the family reinsertion of CPSS users } \\
\hline Not important & 0 & 0.0 & 01 & 0.9 \\
\hline Little important & 0 & 0.0 & 02 & 1.8 \\
\hline Important & 9 & 37.5 & 47 & 41.2 \\
\hline Very important & 15 & 62.5 & 64 & 56.1 \\
\hline \multicolumn{5}{|c|}{ Importance of the intervention of PEP from the ACP for the adoption of healthy lifestyles by CPSS users } \\
\hline Little important & 0 & 0.0 & 01 & 0.9 \\
\hline Important & 3 & 12.5 & 28 & 24.6 \\
\hline Very important & 21 & 87.5 & 85 & 74.6 \\
\hline \multicolumn{5}{|c|}{ Importance of the intervention of PEP from the ACP to reduce the anxiety and fatigue of CPSS users } \\
\hline Little important & 0 & 0.0 & 3 & 2.6 \\
\hline Important & 5 & 20.8 & 30 & 26.1 \\
\hline Very important & 19 & 79.2 & 82 & 71.3 \\
\hline \multicolumn{5}{|c|}{ Importance of the intervention of PEP from the ACP to improve self-esteem of CPSS users } \\
\hline Little important & 0 & 0.0 & 2 & 1.8 \\
\hline Important & 6 & 25.0 & 40 & 35.1 \\
\hline Very important & 18 & 75.0 & 72 & 63.2 \\
\hline \multicolumn{5}{|c|}{ Perception of the level of integration between the ACP and the CPSS } \\
\hline Very poor & 0 & 0.0 & 1 & 0.9 \\
\hline Poor & 6 & 26.1 & 11 & 9.7 \\
\hline Moderate & 8 & 34.8 & 34 & 30.1 \\
\hline Good & 9 & 39.1 & 34 & 30.1 \\
\hline Very good & 0 & 0.0 & 33 & 29.2 \\
\hline
\end{tabular}

PEP: Physical education professional ACP: Academia da Cidade Program, CPSS: Center for Psychosocial Support ITP: Individual Therapeutic Project.

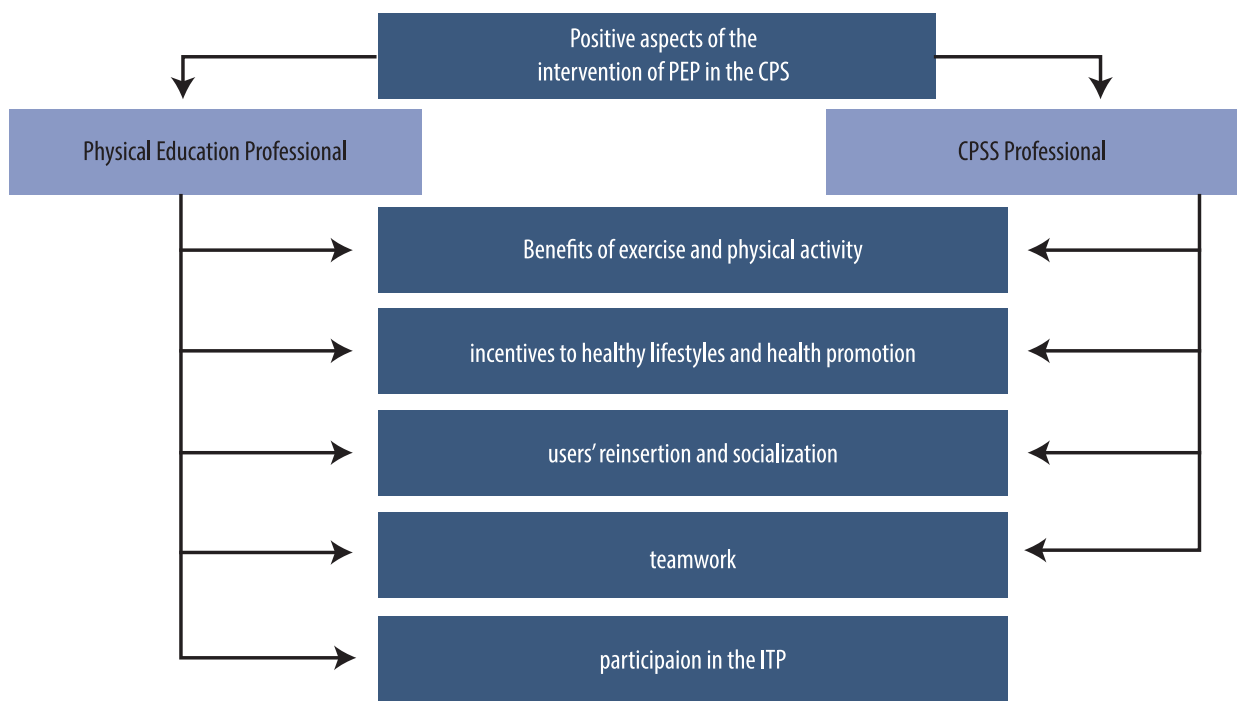

FIGURE 1 - Positive aspects of the intervention of physical education professionals (PEP) in the CPSS. 
physical structure to implement interventions [...]"; Prof. 9ACP "The structure is inadequate to perform group activities [...]"; shortage of Material resources for activities: Prof. 69CPSS "[...] there is not enough material available to implement the exercises [...]"; Prof. $5 A C P$ "Limited material resources [...]"; Acknowledgement given to PEP at the CPSS: Prof. 81CPSS "[...] the non-insertion of PEP in the mental health team [...]"; Prof. 19ACP "Not being an extremely busy professional at the CPSS [...]"; and Limited working hours: Prof. 111CPSS "Reduced-insufficient-working hours [...]"; Prof. 7ACP "Difficulty in participating in other CPSS activities due to reduced working hours" were the subcategories identified in the data provided by the ACP and CPSS professionals.

In addition, CPSS professionals considered the Lack of Ambulatory Health Care Records (AHCR), which generate economic resources to the health units, to be a negative aspect of PEP intervention: Prof. 38CPSS"PEP do not complete AHCRs, even though they perform the actions themselves [...]", and Lack of training in mental health: Prof. 4ACP "[...] lack of initial training to start working at the CPSS and lack of ongoing education [...]" and The fact that the performance of their work activities is not considered to be unhealthy: Prof. $14 A C P$ "[...] the non-acknowledgment of unhealthy issues [...]" were subcategories highlighted by ACP professionals. The category negative aspects of the intervention of PEP from the ACP in the CPSS and its corresponding subcategories are presented in Figure 2.

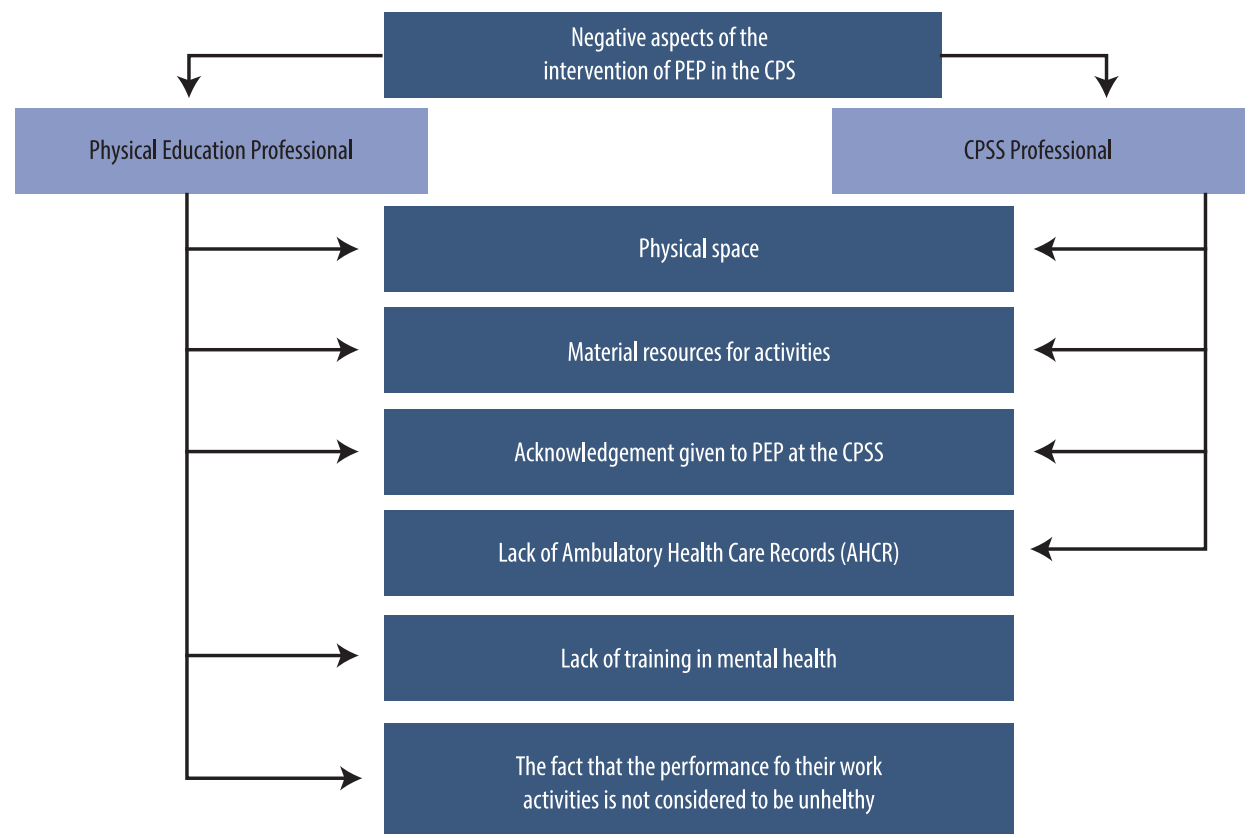

FIGURE 2 - Negative aspects of the intervention of physical education professionals (PEP) in the CPSS.

\section{Discussion}

Our results reveal that CPSS professionals came from different disciplines, which complies with the multidisciplinary team approach recommended for psychosocial care. However, they had no specific training in mental health. Nevertheless, it is important to highlight that currently some courses also offer curricular and extracurricular subjects that address professional training in mental health. Likewise, multidisciplinary residencies in public health, family health and mental health are another possible training source for professionals.

Most respondents from both groups rated the contributions of physical education professionals' participation in the CPSS as "very important" for the development of ITPs, family reinsertion, the adoption of healthy lifestyles, users' 
decreased anxiety and improved self-esteem.

Under this perspective, Physical Education subjects may become powerful therapeutic tools, because they include both senses and meanings that help PEP gather relevant information on users' history and potentials ${ }^{6,10}$. It is, however, important to note that, as reported by the PEP in this study, their lack of training to work at the CPSS and the weak interaction between the CPSS and the ACP may weaken interventions.

Analyzing the responses given to the open-ended questions in the questionnaires, we found that, in the category positive aspects of the intervention of PEP from the $A C P$ in the CPSS, the subcategory Benefits of exercise and physical activity emerged in both groups. It is known that exercise and physical activity play an important role in improving physical and social function, as well as in mental health, contributing to significant quality of life gains. Thus, they could prove to be a therapeutic aid for the treatment of mental disorders ${ }^{18-20}$.

Moreover, PEP interventions in the CPSS bring incentives to healthy lifestyles and health promotion, as recommended in the Brazilian public health policies, and have a positive impact on wellbeing, hygiene and self-esteem. Additionally, they promote users' reinsertion and socialization, because they help improve the interaction between users and functional autonomy ${ }^{10}$.

PEP's proposal of promoting activities that encourage a closer relationship between CPSS users makes socialization a positive aspect of this intervention. Also of note, for the psychosocial rehabilitation and reinsertion of users, it is important that physical education professionals implement practices that target users' real needs, considering social relations that exist beyond the CPSS and treat users as active and autonomous subjects ${ }^{21,22}$.

With regard to the subcategory teamwork, which was also cited by both groups, we found that multi- and interdisciplinary team work are acknowledged as important. In this case, it is considered that, by assuming their social role in a team, professionals admit that they have a specific knowledge base and are able to recognize their importance in the team, but, at the same time, they identify their own limitations and are willing to share knowledge with other team members, filling the lack of knowledge identified ${ }^{23}$.

The importance ascribed to teamwork is in line with the integrated view proposed by the Ministry of Health, in which users' subjectivity and oneness is placed in the foreground of attention and work is performed in an interdisciplinary manner ${ }^{8}$. Thus, the more effective teamwork is built, the greater the diversity of work methods ${ }^{24}$.

Teamwork is essential for the development of ITPs; however, only PEP self-appraised their participation in the development of ITPs as positive. The little importance given by CPSS professionals to this subcategory may be due to the non-participation of some PEP in clinical meetings where cases are discussed and ITPs are created ${ }^{12}$.

Nevertheless, it is interesting to notice that PEP see themselves as participants in the development of ITPs and, although they are not connected to the CPSS, they seem to identify themselves in the therapeutic proposals. Thus, we found that the positive aspects of the intervention of PEP from the ACP in the CPSS are positive because they comply with the care recommended in the current Brazilian mental health model.

The other category analyzed was negative aspects of the intervention of PEP from the ACP in the CPSS. The subcategory inadequate physical space emerged in both groups. This shows a non-compliance with the recommended in the "Manual de Estrutura Física dos Centros de Atenção Psicossocial e Unidades de Acolhimento" 
(Manual on the Physical Structure of shelters and the CPSS) ${ }^{3}$.

According to the manual, the CPSS should provide several different spaces to allow appropriate interaction and therapy participation, including communal areas and collective activities rooms that can be used by PEP. Nevertheless, as most CPSS sites are houses that have been adapted to host CPSS activities and were not originally built to be used as CPSS, they not always provide ample spaces for the performance of activities.

The lack of material resources was also a subcategory mentioned by both ACP and CPSS professionals. In a study published in 2013, the PEP in Recife considered the material resources available at the CPSS to be sufficient but limited ${ }^{12}$. This limitation may represent a problem for the pedagogical implementation of activities included in users' ITP.

With regard to the subcategory limited working hours, both groups classified it as negative aspects of the intervention of PEP from the ACP in the CPSS. Currently, PEP work a 10-hour/week at the CPSS, where they supervise the "Grupo Movimento", perform interdisciplinary activities, participate in technical meetings, supervise the institution, among other activities. There are only three working shifts for the implementation of interventions, which appears to restrict the performance of PEP when compared to other CPSS professionals.

CPSS professionals also considered the lack of Ambulatory Health Care Records (AHCR) to be another negative aspect of PEP intervention. The AHCR was established in 2012 by the Ministry of Health through Ordinance 276. Its aim was to include the monitoring of health actions and services in order to qualify the processing of procedures in the Outpatient Information System (OIS) ${ }^{25}$.

In order to launch a procedure in the AHCR, the professional's Brazilian Occupational Code (BOC) needs to be registered first ${ }^{26}$. Since it they are not connected to the CPSS, the BOC of PEP from the ACP is not compatible with mental health procedures, which makes their registration impossible. This evidences a lack of regulation on PEP's tasks at CPSS in Recife.

The lack of training in mental health and the fact that the performance of their work activities is not considered to be unhealthy were subcategories identified only from the data provided by PEP. In order for them to be able to do their job the best way possible, PEP need to receive appropriate training, because the qualification of mental health services and teams is a determining factor for the success of care ${ }^{27}$.

Conversely, the fact that the performance of their work activities is not considered to be unhealthy evidences another fragility in the relations between ACP and CPSS, because while CPSS professionals - of middle or higher education level - are paid a post differential for (notably) unhealthful conditions, PEP are not, due to the fact that they are connected to the ACP.

Thus, we found that the negative aspects of the intervention of PEP from the ACP in the $C P S S$ are due to structural and work process issues. With its own specific characteristics, such as its connection to the ACP and reduced working hours, the work process of PEP in the CPSS faces many challenges, making it necessary to develop actions and technologies to effectively improve the quality of life of the population ${ }^{12,13}$.

Of note, the interpretation of the results found in this study needs to take into account some limitations, such as difficulties in data collection arising from the characteristics of the two services, the lack of institutional documents related to the intervention of PEP in the CPSS, and the methodological restrictions of cross-sectional studies. Therefore, further research with more complex approach- 
es is warranted to investigate multifactorial aspects of the performance of PEP from the ACP in the CPSS in Recife.

Nevertheless, the findings of this study reveal some key points about the performance of PEP in the context of mental health services in Recife. Positive aspects of this intervention are associated with the therapeutic care process and are necessary contributions to the CPSS. On the other hand, structural and work process issues were found to be negative aspects that need to be improved through new arrangements at management level and better interaction between policies. Finally, we found that, despite the challenges faced in their daily work, the intervention of PEP in the CPSS is considered to be important and to contribute to mental health care provision. Thus, structural and work process issues need to be addressed in order to allow a more qualified and integrated performance from these professionals.

\section{Acknowledgments}

We would like to thank all those who, directly and indirectly, contributed to the performance of this study.

\section{Authors' contributions}

All the authors participated in project design or data analysis and interpretation, in drafting this manuscript and critically reviewing its intellectual content, and approved the final version to be published.

\section{References}

1. Amarante P. Saúde mental, formação e crítica. Rio de janeiro: Laps, 2008.

2. Melo AMC. Notes about the psychiatric reform in Brazil. Cadernos Brasileiros de Saúde Mental. CEP:89. CEP:84-95.

3. Brasil. Ministério da Saúde. Secretaria de Atenção à Saúde. Departamento de Ações Programáticas Estratégicas. Manual on the Physical Structure of Psychosocial Support Centers and Shelters: Guidelines for the implementation of construction projects for CPSS and shelters as psychosocial support sites in the territories. - Brasília: Ministério da Saúde, 2013.

4. Pimenta ES, Romagnoli RC. The Relationship with the Families in the Treatment for Mentally Troubled Patients at the Psychosocial Attention Center. Pesqui Prát Psicossociais. 2008; 3(1): CEP:75-84.

5. Brasil. Ministério da Saúde. Portaria GM 3.088, de 23 de janeiro de 2011, republicada em 30/12/11. Brasília: Ministério da Saúde, 2011.

6. Guimarães AC, Cristiane R, Pascoal A. Social Insertion through Physical Education Practices as Interventional Measures for Severe Psychotic and Neurotic Patients from the CAPS of São João Del-Rei/MG. Pesqui Prát Psicossociais. 2012; 7(2): 254-59.

7. Minelli DS, Soriano JB, Fávaro PE. The Physical Education professional and the intervention in multiprofessional teams. Movimento. 2009; 15(4): 35-62.

8. Brasil. Ministério da Saúde. Secretaria de Atenção à Saúde. Departamento de Ações Programáticas Estratégicas. Saúde mental no SUS: os centros de atenção psicossocial. Brasília: Ministério da Saúde, 2004.

9. Furtado RP, Oliveira MFM, Sousa MF, Vieira PS, Neves RLR, Rios GB, et al. The Work of Physical Education Teachers at Caps: initial approaches. Movimento. 2015; 21(1): 41-52.

10. Wachs F, Fraga AB. Physical education in Centers for Psychosocial Care. Rev. Bras Ciênc Esporte. 2009; 31(1): 93-107.

11. Abib, LT, Fraga AB, Wachs F, Alves CTP. The Body Practices Concerning Mental Health: A Football Workshop Capabilities and Possibilities in a Psychosocial Care Centre. Pensar a Prát. 2010; 13(2): 1-15.

12. Leonidio AR, Lemos EC, Silva PPC, Freitas CMSM. The Physical Education professionals in the Psychosocial Care Center: perception of the limits and potentialities in the working process. Pesqui Prát Psicossociais. 2013; 8(2): 157-65. 
13. Lemos EC, Gouveia GC, Luna CF. Programa Academia da Cidade: A experiência do Recife. In: Gurgel IG, Medeiros KR, Aragão AA, Santana RM. Gestão em Saúde Pública: Contribuições para a política. Recife: Editora UFPE, 2014. 139-53.

14. Rouquayrol MZ, Almeida Filho N. Epidemiology and Health. 6. ed. Rio de Janeiro: MEDSI, 2006.

15. Gil AC. How to prepare research projects. 4ed. São Paulo: Atlas, 2002.

16. Minayo MCS. The challenge of knowledge: qualitative health research. 2 ed. São Paulo: Hucitec Abrasco, 1993.

17. Bardin L. Content Analysis. Lisboa: Editora 70, 2011.

18. Melo B, Moraes HS, Silveira H, Oliveira N, Deslandes AC, Laks J. Effects physical training on quality of life in older adults with major depression. Rev Bras Ativ Fís Saúde. 2014; 19(2): 205-14.

19. Adamoli NA, Azevedo MR. Patterns of physical activity of people with chronic mental and behavioral disorders. Ciênc. Saúde Coletiva. 2009; 14(1): 243-51.

20. Vieira, JLL. The regular physical exercise's practice as complementary therapy to the treatment of depressed women. J Bras Psiquiatr. 2007; 56(1): 23-8.

21. Barros S, Oliveira MAF, Silva ALA. Innovative practices for health care. Rev Esc Enferm USP. 2007; 41(spe): 815-9.

22. Kantorski LP, Coimbra VCC, Demarco DA, Eslabão AD, Nunes CK, Guedes AC. The importance of therapeutic support activities for the attention in a Psychosocial Care Center. Rev Enferm Saúde. 2011; 1(1): 4-13.

23. Ladvocat MB, Teves N. Representation of The Social Place of the Professional of Physical Education in The Psychosocial Care Centers for Children and Adolescents, RJ. Arq Mov. 2011; 7(1): 34-51.

24. Peduzzi M. Multiprofessional healthcare team: concept and typology. Rev Saúde Pública. 2011; 35(1): 103-9.

25. Brasil. Ministério da Saúde. Secretaria de Atenção à Saúde. Departamento da atenção Básica. Portaria no 276, de março de 2012. Brasília: Ministério da Saúde, 2012.

26. Brasil. Ministério da Saúde. Secretaria de Atenção à Saúde. Departamento de Regulação, Avaliação e Controle. Coordenação Geral de Sistemas de Informação. AHCR - Ambulatory Health Care Records: System Operation Manual. Brasília: Ministério da Saúde, 2009.

27. Mânglia EF, Muramoto MT, Marques ALM. Interprofessional education and Mental Health Services on the context of SUS: study about the insertion of graduates of the Course of Occupational Therapy - FMUSP. Rev. Ter Ocup Univ. 2010; 21(2): 148-57.

CORRESPONDING AUTHOR

AMELIANE DA CONCEIÇÃO REUBENS LEONIDIO

ameliane.reubens@yahoo.com.br
Rua Manuel de Carvalho, 267, apt.101,

Aflitos, Recife - Pernambuco, Brazil.

CEP:52050-370

Phone: (81) 3451-3671
RECEIVED $\quad 02 / 12 / 2015$

REVISED $\quad 30 / 01 / 2016$

APPROVED $\quad 31 / 01 / 2016$ 